\title{
Perancangan Sistem Informasi Akuntansi Penerimaan Kas Pada CV Bintang Alpro Jakarta
}

\author{
Rini Suwartika Kusumadiarti ${ }^{1}$, Ade Andriany ${ }^{2}$ \\ Teknik Informatika Komputer dan Komputerisasi Akuntansi, Politeknik Fiksi Ganesha Bandung dan Politeknik Fiksi \\ Ganesha Bandung \\ Jl. Gatot Subroto No. 301, Maleer, Kecamatan Batununggal, Kota Bandung, Jawa Barat 40274 \\ rinisuwartika@yahoo.com
}

\begin{abstract}
Abstact - Accounting for Cash Receipts is a record that is made to carry out cash receipts and cash sales activities or from receivables that are ready and free to use for general company activities. CV. Bintang Alpro Jakarta is a company engaged in the field of Office Stationery Provider Services. In the data processing system CV. Bintang Alpro is still lacking and encountered several obstacles, namely: The process of recording cash receipts is less efficient, cash receipts data are easily lost and making reports that still use manual systems that are less accurate so that the need for cash receipts systems that are more effective and efficient in the form of applications. Data collection methods used in this study are direct observation to the place of research, interviews and literature review. Based on this the results of the research carried out is preceded by an analysis of the process of the running system and then look for problems that occur and designed a desktop-based cash receipts application. Some suggestions for solving these problems include: Developing the system further, and doing system maintenance regularly.
\end{abstract}

Keywords — System Information, Cash Receipt Disbursement.

Abstrak-Akuntansi Penerimaan Kas adalah suatu catatan yang dibuat untuk melaksanakan kegiatan penerimaan uang dan penjualan tunai atau dari piutang yang siap dan bebas digunakan untuk kegiatan umum perusahaan Pada sebuah perusahaan hal ini dianggap penting untuk keberlangsungan kegiatan perusahaaan. CV. Bintang Alpro Jakarta merupakan perusahaan yang bergerak dalam bidang Jasa Penyedia Alat Tulis Kantor . Dalam sistem pengolahan datanya CV. Bintang Alpro masih terbilang kurang dan menemui beberapa kendala, yaitu : Proses pencatatan penerimaan kas datanya kurang efisien, data penerimaan kas mudah hilang dan pembuatan laporan yang masih menggunakan sistem manual yang kurang akurat sehingga diperlukannya sistem penerimaan kas yang lebih efektif dan efisien dalam bentuk aplikasi. Metode pengumpulan data yang digunakan dalam penelitian ini adalah dengan melakukan observasi langsung ketempat penelitian, wawancara dan kajian pustaka. Berdasarkan hal tersebut hasil penelitian yang dilakukan adalah diawali dengan analisis proses dari sistem yang berjalan kemudian dicari permasalahan yang terjadi dan dirancanglah aplikasi Penerimaan kas berbasis dekstop. Beberapa saran untuk menyelesaikan permasalahan tersebut, diantaranya :Mengembangkan sistem lebih lanjut,dan dilakukannya perawatan sistem secara berkala.

Kata Kunci — Sistem Informasi, Penerimaan Kas

\section{A. Latar Belakang Masalah}

\section{PENDAHULUAN}

Perkembangan Teknologi yang semakin pesat saat ini menuntut berbagai kalangan untuk selalu melakukan perubahan, terutama dalam hal pemenuhan kebutuhan akan informasi. Kebutuhan akan informasi yang dirasa sangat penting bagi kalangan pengusaha, lembaga formal maupun nonformal diharapkan dapat mereka peroleh dengan serba cepat dan tepat.

Seiring juga perkembangan dunia usaha yang kian pesat dan persaingan antar perusahaan dalam mencapai profit dalam menjalankan usahanya, sehubungan hal itu 
penerapan teknologi komputer yang disebut dengan sistem komputerisasi kini tidak dapat dihindari lagi, sebut saja dibidang perkantoran, perdagangan dan lainnya yang sangat membutuhkan informasi dan pengolahan data yang cepat, akurat dan efisien harus segera di wujudkan.

Dalam sistem pengolahan datanya $\mathrm{CV}$. Bintang Alpro masih terbilang kurang dan menemui beberapa kendala, yaitu proses pencatatan penerimaan kas datanya kurang efisien, data penerimaan kas mudah hilang, dan pembuatan laporan yang masih menggunakan sistem manual yang kurang akurat.

Kendala tersebut disebabkan belum digunakannya sistem penerimaan kas yang sudah terkomputerisasi, untuk itu sangat diperlukan adanya sistem penerimaan kas yang sudah terkomputerisasi sehingga kendalakendala diatas dapat teratasi. Dengan sistem komputerisasi data yang dihasilkan akan akurat dan lebih efisien.

\section{B. Pokok Permasalahan}

Berdasarkan latar belakang masalah yang telah penulis uraikan, maka pokok permasalahan dalam penelitian ini yaitu :

1. Proses pencatatan dan pembuatan laporan yang dilakukan menggunakan sistem manual sehingga memakan waktu yang lama.

2. Kurangnya pengetahuan manajemen tentang manfaat sistem informasi akuntansi terkomputerisasi.

\section{Tujuan Penelitian}

1. Memperbaiki sistem pencatatan dan pembuatan laporan berbasis aplikasi yang diharapkan dapat meningkatkan efisiensi dan efektivitas perusahaan.

2. Bertambahnya pengetahuan pihak manajemen dalam menggunakan sistem informasi akuntansi berbasis komputer

\section{KAJIAN TEORITIS}

\section{A. Pengertian Perancangan}

Menurut Azhar Susanto (2004:331) menjelaskan dalam buku berjudul Sistem Informasi Manajemen Konsep dan Pengembangannya yaitu : "Perancangan adalah spesifikasi umum dan terinci dari pemecahan masalah berbasis komputer yang telah dipilih selama tahap analisis" [1],

B. Pengertian Sistem

Menurut Jogiyanto (2005:34) bahwa " sistem adalah suatu jaringan kerja dari prosedur-prosedur yang saling berhubungan, berkumpul bersama-sama untuk melakukan suatu kegiatan atau untuk menyelesaikan suatu sasaran tertentu" [2].

\section{Pengertian Informasi}

Menurut Azhar Susanto (2004:46) dalam bukunya Sistem Informasi Akuntansi mendefinisikan informasi sebagai berikut: "Informasi adalah hasil pengolahan data yang memberikan arti dan manfaat" [1].

D. Pengertian Sistem Informasi

Sistem informasi didefinisikan oleh Robert A. Leitch dan K. Roscoe Davis dalam Jogianto HM (2005:11) "Sistem Informasi adalah suatu sistem di dalam suatu organisasi yang mempertemukan kebutuhan pengolahan transaksi harian, mendukung operasi, bersifat manajerial dan kegiatan strategi dari suatu organisasi dan menyediakan pihak luar tertentu dengan laporan-laporan yang diperlukan" [2].

\section{E. Pengertian Akuntansi}

Soemarso S.R (2004:3) “Akuntansi sebagai proses mengidentifikasi, mengukur dan melaporkan informasi ekonomi, untuk memungkinkan adanya penilaian dan keputusan yang jelas dan tegas bagi mereka yang menggunakan informasi tersebut" [3].

F. Pengertian Sistem Informasi Akuntansi

Menurut Stephen A. Mouscove dalam Jogianto (2005:17) "Sistem Informasi Akuntansi yaitu suatu komponen organisasi yang mengumpulkan, mengklasifikasikan, memproses, menganalisa, mengkomunikasikan informasi, mengambil keputusan dan orientasi financial bagi pihak luar dan pihak perusahaan (secara prinsip-prinsip manajemen) [2].

G. Pengertian Kas

Menurut Thedorus M. Tuanakotta (2000:150) dalam buku yang berjudul Teori Akuntansi "Kas sangat penting karena sifatnya yang liquid, mudah sebagai alat pertukaran, dan menunjukan daya beli secara umum, kas disini uang tunai maupun saldo kas dalam bank" [4].

\section{H. Pengertian Akuntansi Penerimaan Kas}

"Akuntansi Penerimaan Kas adalah suatu catatan yang dibuat untuk melaksanakan kegiatan penerimaan uang dan penjualan tunai atau dari piutang yang siap dan bebas digunakan untuk kegiatan umum perusahaan" [5].

I. Pengertian Visual Studio 2010

"Microsoft Visual Studion 2010 adalah merupakan sebuah perangkat lunak lengkap (suite) yang dapat digunakan untuk melakukan pengembangan aplikasi, aplikasi bisnis, personal, dan komponen aplikasi lainnya". Belajar adalah suatu proses yang kompleks yang terjadi pada diri setiap orang sepanjang hidupnya (Azhar Arsyad, 2011:1). Batasan diatas dikuatkan sadiman, dkk (2009:2) dalam bukunya yang berjudul media pendidikan mengemukakan belajar adalah suatu proses yang kompleks yang terjadi pada semua orang dan berlangsung seumur hidup, sejak dia masih bayi hingga keliang lahat nanti.

\section{METODOLOGI PENELITIAN}

A. Teknik Pengumpulan Data

Dalam pengumpulan data, data yang diperlukan untuk penulisan laporan ini, penulis menggunakan 
beberapa metode pengumpulan data, diantaranya ialah sebagai berikut :

\section{Metode Observasi}

Dalam hal ini penulis melakukan peninjauan secara langsung kelapangan dengan menganalisa pelaksanaan sistem yang sedang berjalan di CV. Bintang Alpro.

2. Metode Wawancara

Yaitu dengan pengumpulan data serta sebagai informasi dengan cara bertanya langsung kepada narasumber atau seseorang yang di anggap ahli serta mengetahui permasalahan yang menjadi kendala. Ada beberapa narasumber yang di wawancarai yakni Direktur Utama CV. Bintang Alpro, Bendahara dan Administrasi.

3. Metode Studi Pustaka

Penelitian yang dilakukan untuk mendapatkan informasi yang terkait dengan permasalahan yang akan diteliti, penelitian kepustakaan dilakukan sebagai usaha guna memperoleh data yang bersifat teori sebagai pembanding dengan data penelitian yang diperoleh. Data-data yang diperoleh oleh penulis dari studi pustaka yaitu berupa buku-buku, literatur, website, catatan kuliah dan tulisan lain yang berhubungan dengan penelitian.

4. Metode Pengembangan Sistem

Metode pengembangan perangkat lunak yang digunakan adalah metode Linear Sequential atau Waterfall. Linear sequential (atau disebut juga "classic life cycle" atau waterfall method")

\section{HASIL DAN PEMBAHASAN}

A. Analisis Proses

Proses ini bertujuan untuk mengetahui langkah langkah atau proses apa saja yang telah dilakukan pada sistem yang sedang berjalan seperti, penerimaan kas yang masih manual. Dalam analisis sistem ini menggunakan metode analisis terstruktur, dimana datadata analisisnya disajikan dalam bentuk Diagram Konteks, Data Flow Diagram (DFD), Entity Relationship Diagram (ERD). Berikut adalah analisis proses yang sedang berjalan di CV. Bintang Alpro :

\section{Flowmap penerimaan kas sedang berjalan}

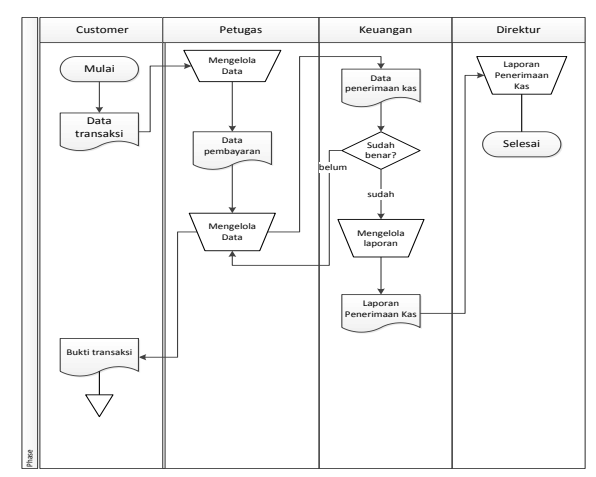

Gambar 1. Flowmap penerimaan kas yang sedang berjalan dimana alur system penerimaan kas masih bersifat manual

\section{B. Perancangan Sistem}

Alur sistem yang diusulkan untuk merancang Sistem Informasi Penerimaan Kas di CV. Bintang Alpro.

Flowmap system informasi penerimaan kas yang diusulkan

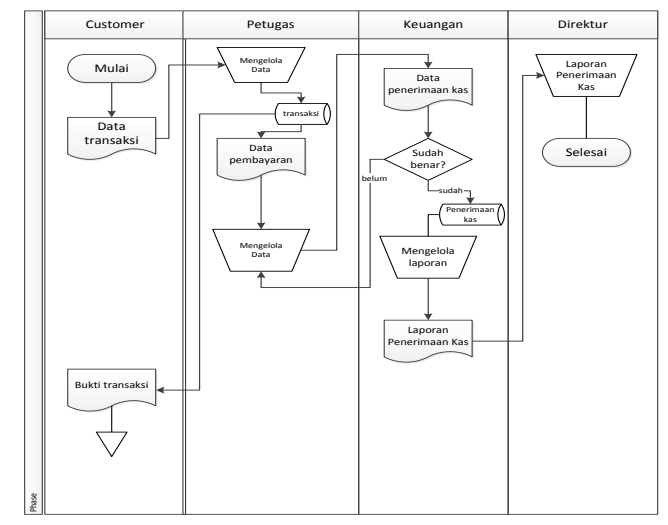

Gambar 2. FlowMap system penerimaan kas yang diusulkan dimana ada penambahan pennggunaan media penyimpan dalam bentuk database sebagai ciri adanya penggunaan komputerisasi

\section{Data Flow Diagram (DFD)}

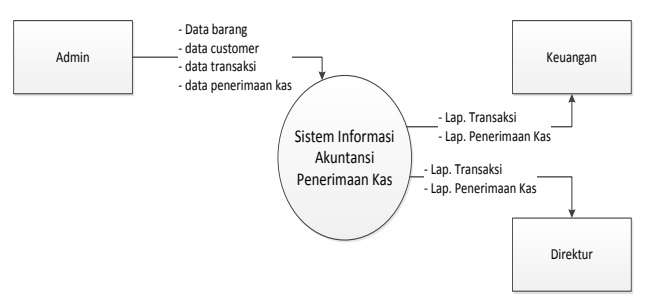

Gambar 3. Diagram contex proses Sistem Informasi Akuntansi penerimaan kas dengan entitas terdiri dari Admin, Bagian keuangan dan Direktur

2. DFD Level 0 yang diusulkan 


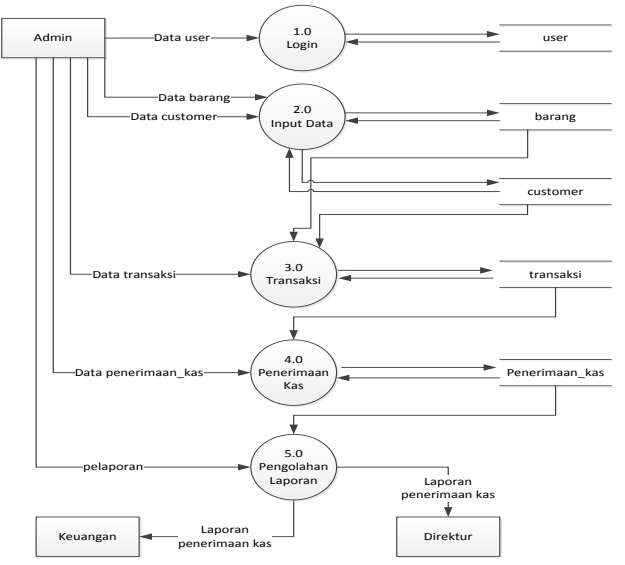

Gambar 4. DFD Level 0 SIA Penerimaan Kas dimana proses yang dilakukan adalah login, input data, gransaksi, penerimaan kas dan proses pelaporan

3. DFD level 1 proses login

a. Proses 1 : Login

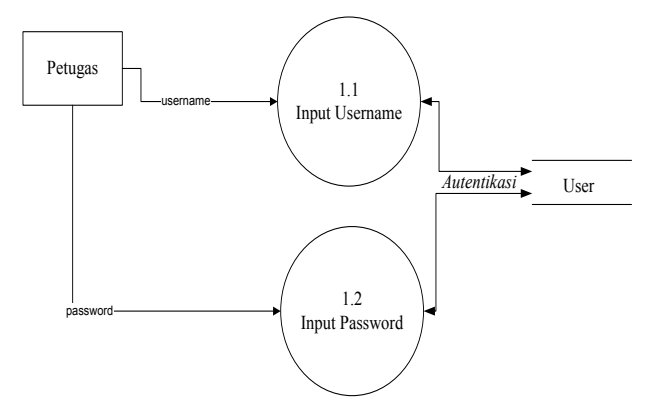

Gambar 5. DFD lvl 1 Proses Login dimana petuga menginputkan username dan password untuk dapat mengakses aplikasi

b. Proses 2 : Kelola Data User

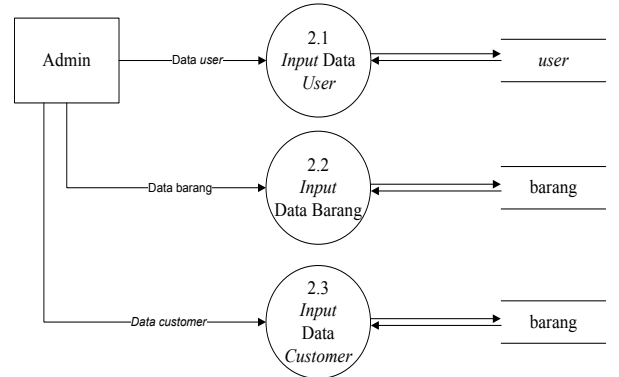

Gambar 6. Proses Kelola Data User dimana admin dapat menginputkan data user, input data barang dan input data customer

c. Proses 3 :Kelola Data Transaksi

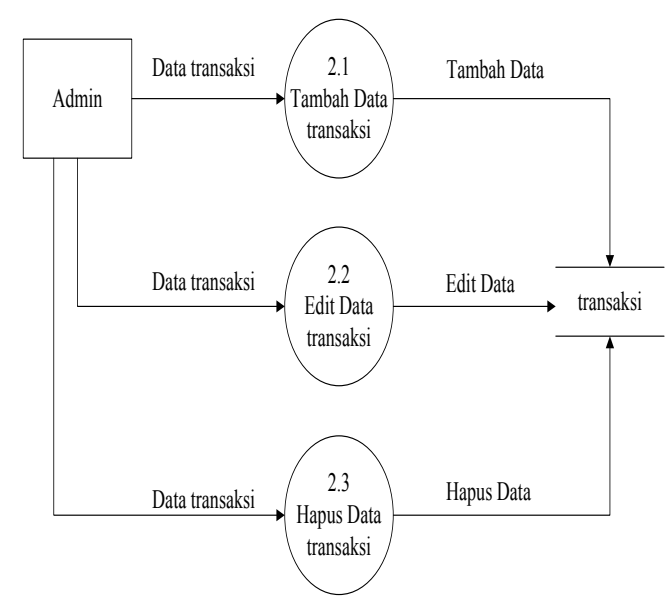

Gambar 7 DFD Level 1 proses kelola Data Transaksi dimana admin dapat melakukan proses tambah data transaksi, edit data transaksi dan hapus data transaksi

d. Proses 4 : Kelola Data Transaksi

\section{Penerimaan Kas}

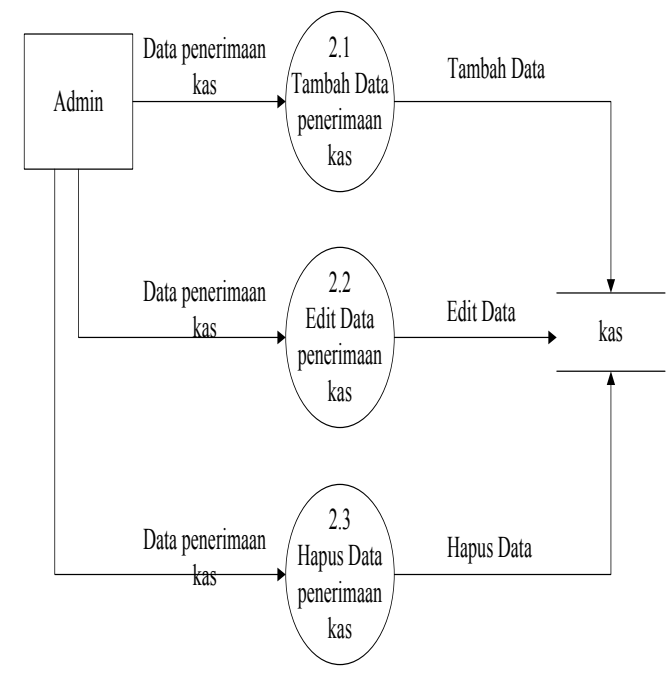

Gambar 8. DFD level 1 proses kelola data transaks penerimaan kas dimana admin dapat melakukan proses tambah data penerimaan kas, edit data penerimaan kas dan hapus data penerimaan kas

e. Proses 5 : Pelaporan

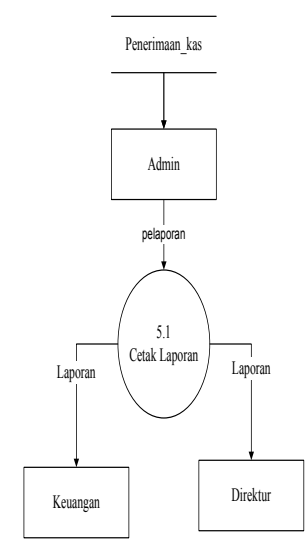




\section{Rancangan Basis Data}

Gambar 9. DFD Level 1 proses pelaporan, dimana admin dapat melakukan pelaporan yang nantinya hasil laporan diserahkan ke bagian keuangan dan direktur

\section{Entity Relationship Diagram (ERD)}

Dalam ERD ini menjelaskan tentang data yang tersimpan dari perancangan sistem informasi Akuntansi Penerimaan Kas.

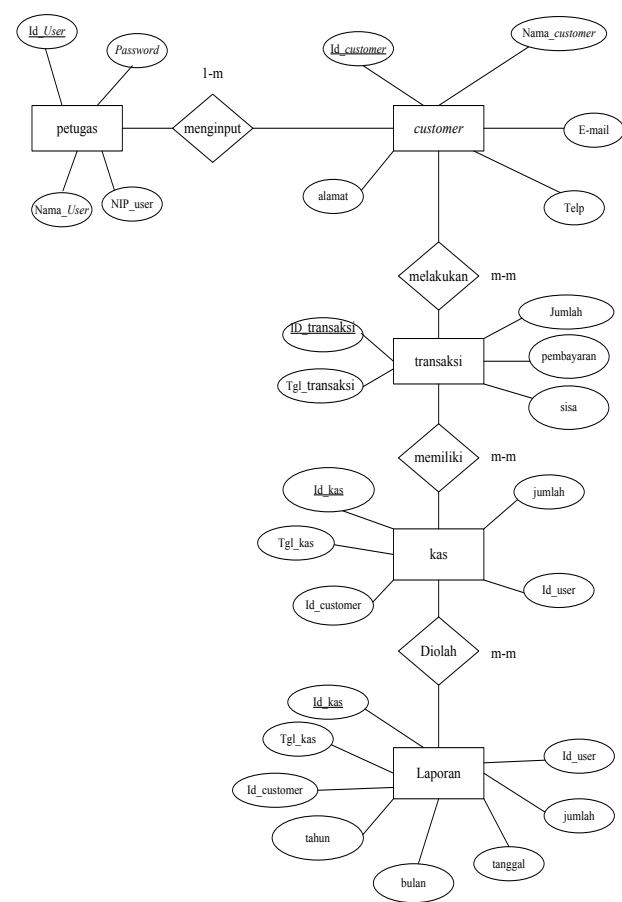

Gambar 10. ERD system informasi akuntansi penerimaan kas dimana alurnya adalah petugas menginput data customer, dimana customer setelah customer melakukan transaksi, setiap customer akan memiliki data penerimaan kas sehingga dapat diolah dan dilakukan pelaporan

\section{Rancangan Masukan}

Rancangan masukan pada sistem informasi penerimaan kas ini berupa inputan dari form login, form user, form customer, form barang, form transaksi, form kas, untuk memenuhi kebutuhan pemakai.

TABEL I

\begin{tabular}{|c|l|l|l|l|}
\hline No & $\begin{array}{c}\text { Nama } \\
\text { Dokumen }\end{array}$ & \multicolumn{1}{|c|}{ Fungsi } & Sumber & Media \\
\hline 1 & Data User & $\begin{array}{l}\text { Mengelola } \\
\text { data user }\end{array}$ & user & Komputer \\
\hline 2 & $\begin{array}{l}\text { Data } \\
\text { Customer }\end{array}$ & $\begin{array}{l}\text { Mengelola } \\
\text { data customer }\end{array}$ & admin & Komputer \\
\hline 3 & Data Barang & $\begin{array}{l}\text { Mengelola } \\
\text { data pegawai }\end{array}$ & Admin & Komputer \\
\hline 4 & $\begin{array}{l}\text { Data } \\
\text { Transaksi }\end{array}$ & $\begin{array}{l}\text { Mengelola } \\
\text { data } \\
\text { penghasilan }\end{array}$ & admin & Komputer \\
\hline
\end{tabular}

\begin{tabular}{|c|l|l|l|l|}
\hline 5 & Data Kas & $\begin{array}{l}\text { Mengelola } \\
\text { datapenerimaa } \\
\text { nkas }\end{array}$ & admin & Komputer \\
\hline
\end{tabular}

\section{E. Rancangan Keluaran}

Rancangan keluaran yang dihasilkan dari sistem berupa laporan penerimaan kas atas seluruh transaksi dalam perusahaan.

TABEL II

TABEL RANCANGAN KELUARAN

\begin{tabular}{|c|l|}
\hline $\begin{array}{c}\text { Nama } \\
\text { Dokumen }\end{array}$ & $\begin{array}{l}\text { 1. Kwitansi Transaksi } \\
\text { 2. Laporan Penerimaan Kas } \\
\text { 3. Jurnal Penerimaan Kas }\end{array}$ \\
\hline Fungsi & Sebagai laporan penerimaan kas \\
\hline Sumber & Bendahara \\
\hline Media & Kertas \\
\hline Frekuensi & Bulanan dan tahunan \\
\hline Jumlah & 2 Rangkap \\
(Rangkap) & \\
\hline Format & $\begin{array}{l}\text { Berbentuk kertas yang sudah di } \\
\text { print out yang berisi } \\
\text { 1. Kwitansi Transaksi }\end{array}$ \\
& $\begin{array}{l}\text { 2. Laporan Penerimaan Kas } \\
\text { 3. Jurnal Penerimaan Kas }\end{array}$ \\
\hline
\end{tabular}

F. Spesifikasi Hardware dan Software

1. Hardware

- 1 unit komputer dengan spesifikasi CPU : Proc. Intel Celeron 1.5 Ghz, HDD: $40 \mathrm{~GB}$, RAM :1 GB, VGA resolusi minimal 1366 x 768 px, warna 32 bit.

- Monitor : LCD/CRT minimal 14" mendukung resolusi 1366x768 px

- Keyboards \& Mouse

- Printer

2. Software

- Sistem operasi Windows XP Professional ke atas

- plikasi Bahasa Pemograman Microsoft Visual Studio 201

- Aplikasi Database Microsoft Access 2003

\section{G. Implementasi Sistem}

1. Login

Gambar di bawah ini merupakan tampilan login dimana user yang dapat mengakses adalah admin dan Manajer bagian keuangan. 


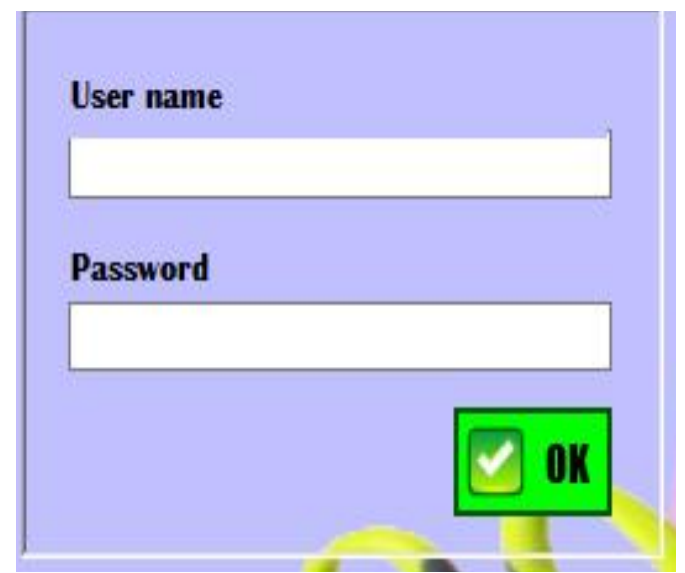

Gambar 12. Rancangan form Login dimana user yang dapat mengakses adalah admin dan Manajer bagian keuangan.

2. Мепи Utama

Gambar dibawah ini merupakan tampilan menu utama yang akan tampil setelah proses login.

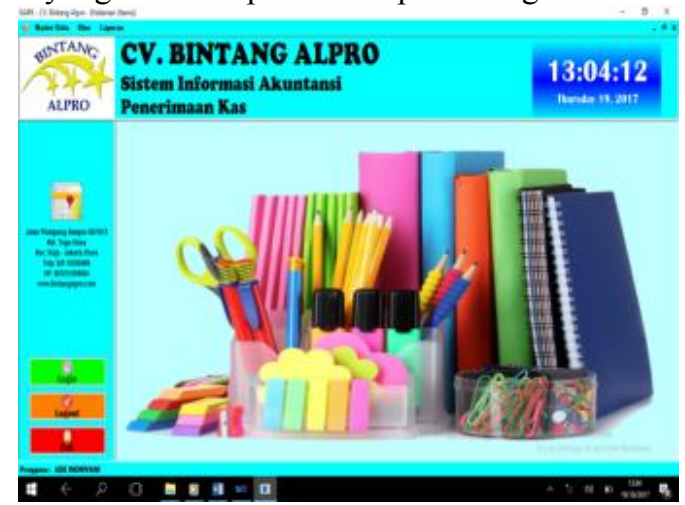

Gambar 13. Rancangan Menu Utama dimana tampilan antar muka ini merupakan tampilan menu utama yang akan tampil setelah proses login

3. Form User

Gambar dibawah ini merupakan form input data user

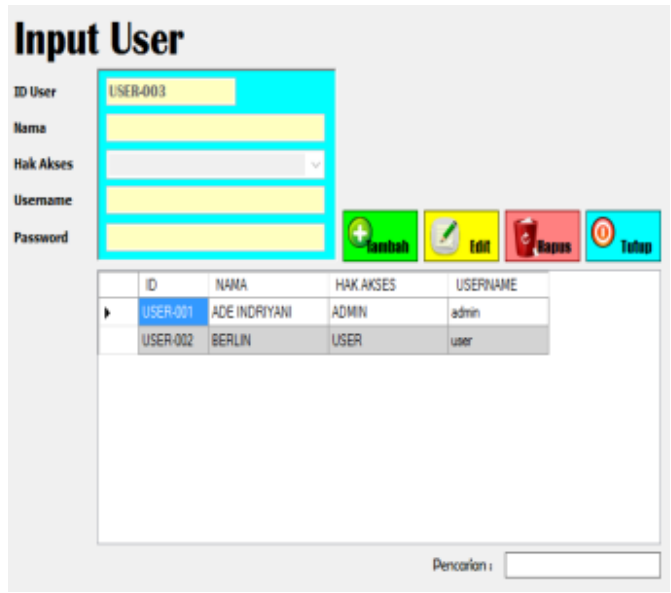

Gambar 14. rancangan Form User dimana admin menginputkan data user berupa id user, nama, hak akses ,username dan password

4. Form Barang

Gambar dibawah ini merupakan form input data barang

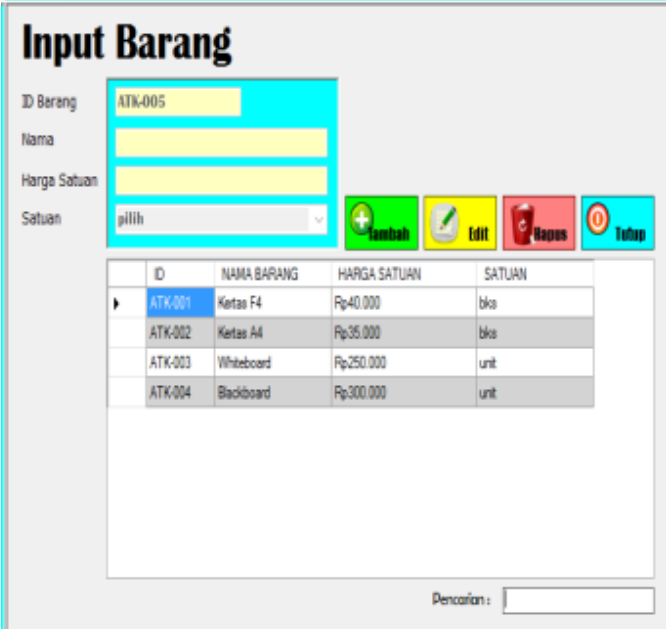

Gambar 15. Rancangan Form Barang dimana data yang diinputkan adalah ID barang, nama barang, harga satuan dan type satuan barang

\section{Form Customer}

Gambar dibawah ini merupakan form input data customer

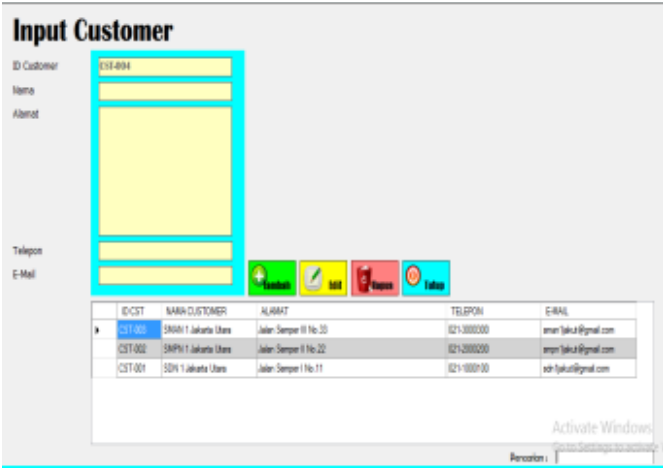

Gambar 16 Rancangan form customer dimana admin dapat menginputkan id customer, nama , alamat, telepon dan email

\section{Form Transaksi}

Gambar dibawah ini merupakan form transaksi yang merupakan aplikasi yang dapat menghitung total pembelian barang 


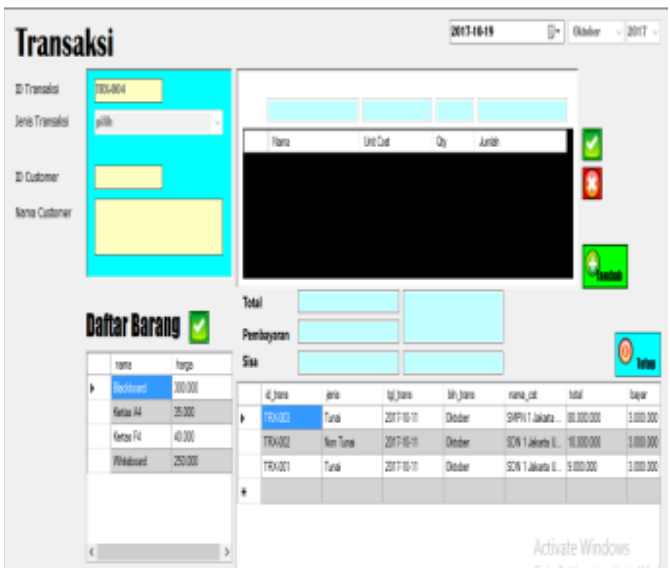

Gambar 17. Gambar dibawah ini merupakan form transaksi yang merupakan aplikasi yang dapat menghitung total pembelian barang

7. Form Penerimaan Kas

Gambar dibawah ini merupakan form penerimaan kas yang dapat merekap penerimaan dari total penerimaan barang

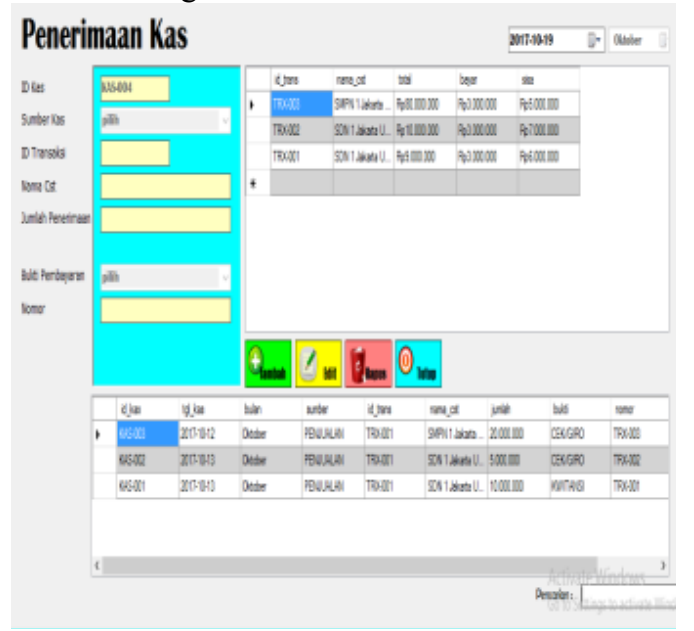

Gambar 18. Rancangan form kas yang dapat merekap penerimaan dari total penerimaan barang

\section{Form Set Laporan Transaksi}

Gambar dibawah ini merupakan form yang dapat menampilkan rekap laporan transaksi yang sudah dilakukan. Pelaporan dapat dilakukan berdasarkan Harian, Bulanan dan Tahunan.

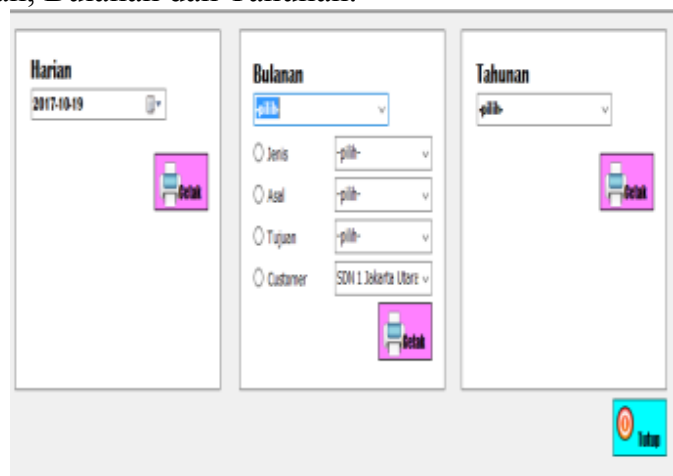

Gambar 19. Rancangan laporan transaksi yang dapat menampilkan rekap laporan transaksi yang sudah dilakukan. Pelaporan dapat dilakukan berdasarkan Harian, Bulanan dan Tahunan

9. Form Set Laporan Kas

Gambar dibawah ini merupakan form yang dapat menampilkan rekap laporan kas yang sudah dilakukan. Pelaporan dapat dilakukan berdasarkan Harian, Bulanan dan Tahunan

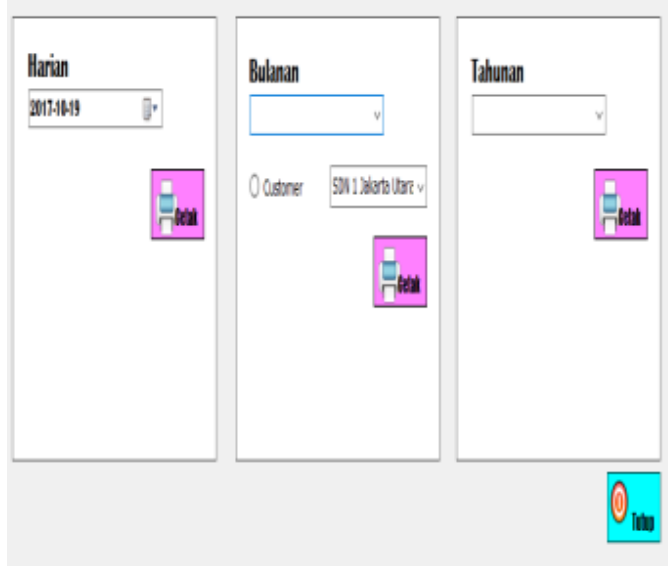

Gambar 20. Rancangan Laporan Kas yang dapat menampilkan rekap laporan kas yang sudah dilakukan. Pelaporan dapat dilakukan berdasarkan Harian, Bulanan dan Tahunan.

\section{Form Laporan Transaksi}

Gambar dibawah ini merupakan form yang dapat menampilkan rekap laporan transaksi yang sudah dilakukan

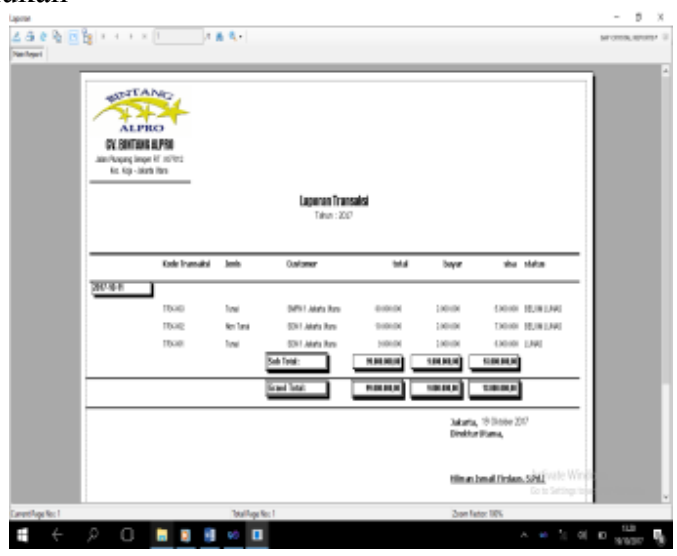

Gambar 21. Rancangan Laporan Kas merupakan form yang dapat menampilkan rekap laporan transaksi yang sudah dilakukan dan dapat dicetak

\section{Form Laporan Kas}

Gambar dibawah ini merupakan form yang dapat menampilkan rekap laporan kas yang sudah dilakukan. 


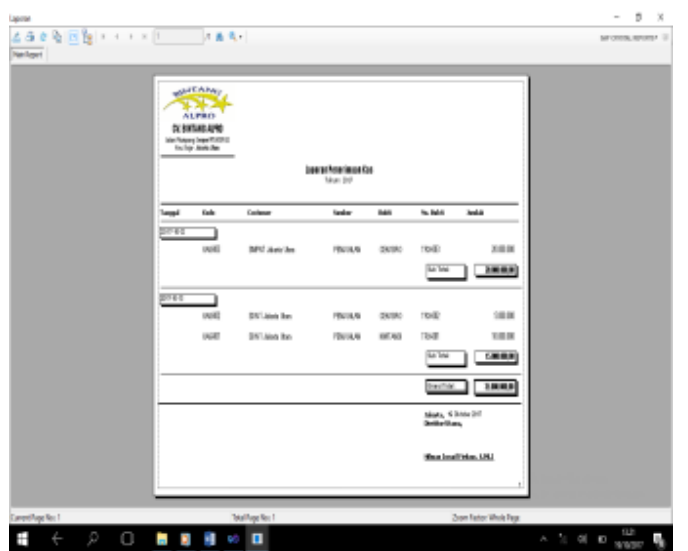

Gambar 22. Rancangan Laporan Kas dimana form ini dapat menampilkan rekap laporan kas yang sudah dilakukan dan dapat dicetak

H. Hasil Pengujian

Pengujian sistem informasi ini menggunakan metode pengujian blackbox. Pengujian Blackbox berfokus pada persyaratan fungsional sistem informasi yang dibuat dan dilakukan selama proses pembuatan program. Pengujian Blackbox yaitu penguajian yang dilakukan terhadap fungsionalitas perangkat lunak tanpa melihat struktur internal program. Sehingga memungkinkan pembuat program atau petugas penguji mendapat serangakaian kondisi input yang sepanuhnya dengan menggunakan semua persyaratan fungsioanal untuk suatu program. Penguji Black box, cendrung diaplikasikan pada tahap akhir pengujian.

TABEL III

RENCANA PENGUJIAN

\begin{tabular}{|l|l|l|}
\hline \multicolumn{1}{|c|}{$\begin{array}{c}\text { Item } \\
\text { Penggujian }\end{array}$} & \multicolumn{1}{|c|}{ Deskripsi } & \multicolumn{1}{c|}{$\begin{array}{c}\text { Jenis } \\
\text { Pengujian }\end{array}$} \\
\hline Login & $\begin{array}{l}\text { Melakukan login } \\
\text { kedalam system }\end{array}$ & Black Box \\
\hline Form User & $\begin{array}{l}\text { Menambahkan } \\
\text { Data Customer }\end{array}$ & Black Box \\
\hline Form Customer & $\begin{array}{l}\text { Untuk } \\
\text { mengganti } \\
\text { sebagai user }\end{array}$ & Black Box \\
\hline Form Barang & $\begin{array}{l}\text { Menambahkan } \\
\text { Data Wilayah }\end{array}$ & Black Box \\
\hline Form Transaksi & $\begin{array}{l}\text { Menginput Data } \\
\text { transaksi }\end{array}$ & Black Box \\
\hline $\begin{array}{l}\text { Form } \\
\text { Pembayaran }\end{array}$ & $\begin{array}{l}\text { Menginput Data } \\
\text { pembayaran }\end{array}$ & Black Box \\
\hline $\begin{array}{l}\text { Form } \\
\text { Penerimaan } \\
\text { Kas }\end{array}$ & $\begin{array}{l}\text { Menambah } \\
\text { analisa laporan }\end{array}$ & Black Box \\
\hline $\begin{array}{l}\text { Form Laporan } \\
\text { Transaksi }\end{array}$ & $\begin{array}{l}\text { Hasil Data } \\
\text { Laporan }\end{array}$ & Black Box \\
\hline $\begin{array}{l}\text { Form Laporan } \\
\text { Penerimaan } \\
\text { Kas }\end{array}$ & $\begin{array}{l}\text { Hasil Data } \\
\text { Laporan }\end{array}$ & Black Box \\
\hline
\end{tabular}

TABEL IV

PENGUJIAN LOG IN

\begin{tabular}{|l|l|}
\hline \multicolumn{2}{|c|}{ Kasus dan Hasil UJi ( Data Normal) } \\
\hline Data Masukan & $\begin{array}{l}\text { Username = admin, password = } \\
12345\end{array}$ \\
\hline Yang diharapkan & $\begin{array}{l}\text { Log in berhasil, Masuk ke bagian } \\
\text { menu utama }\end{array}$ \\
\hline Pengamatan & $\begin{array}{l}\text { Log in berhasil, Masuk ke from } \\
\text { Menu utama }\end{array}$ \\
\hline Kesimpulan & (x) diterima, () ditolak \\
\hline Kasus dan Uji Hasil ( Data Salah ) \\
\hline Data masukan & Data log In yang diinputkan salah \\
\hline $\begin{array}{l}\text { Yang } \\
\text { diharapkan }\end{array}$ & $\begin{array}{l}\text { Log in yang diinputkan salah dan } \\
\text { menampilkan pesan kesalahan } \\
\text { berupa pesan dialog }\end{array}$ \\
\hline Pengataman & $\begin{array}{l}\text { User harus sesuai dengan data yang } \\
\text { tersimpan di data base }\end{array}$ \\
\hline Kesimpulan & (x) Diterima, ( ) Ditolak \\
\hline
\end{tabular}

TABEL $\mathrm{V}$

PENGUJIAN FROM PETUGAS/USER

\begin{tabular}{|c|c|}
\hline \multicolumn{2}{|c|}{ Kasus dan Hasil UJi ( Data Normal) } \\
\hline Data Masukan & $\begin{array}{l}\text { Username = admin, password = } \\
12345 \text {, Id User, Id Customer, } \\
\text { Nama, }\end{array}$ \\
\hline Yang diharapkan & $\begin{array}{l}\text { Data petugas berhasil disimpan } \\
\text { kedalam database }\end{array}$ \\
\hline Pengamatan & $\begin{array}{l}\text { Data berhasil dimasukan kedalam } \\
\text { data User }\end{array}$ \\
\hline Kesimpulan & (x) Diterima, ( ) Ditolak \\
\hline \multicolumn{2}{|c|}{ Kasus dan Uji Hasil ( Data Salah ) } \\
\hline Data masukan & Data User yang diinputkan salah \\
\hline Yang diharapkan & $\begin{array}{l}\text { Data User yang diinputkan salah } \\
\text { dan menampilkan pesan kesalahan } \\
\text { berupa pesan dialog }\end{array}$ \\
\hline Pengataman & $\begin{array}{l}\text { Tidak dapat memasukan username } \\
\text { yang sama }\end{array}$ \\
\hline Kesimpulan & (x) Diterima, ( ) Ditolak \\
\hline \multicolumn{2}{|r|}{$\begin{array}{c}\text { TABEL VI } \\
\text { PENGUJIAN FORM CUSTOMER }\end{array}$} \\
\hline \multicolumn{2}{|c|}{ Kasus dan Hasil UJi ( Data Normal) } \\
\hline Data Masukan & $\begin{array}{l}\text { Id Customer, tgl daftar, nama, } \\
\text { alamat,asal,tlp,email }\end{array}$ \\
\hline Yang diharapkan & $\begin{array}{l}\text { Data customer berhasil disimpan ke } \\
\text { database }\end{array}$ \\
\hline Pengamatan & $\begin{array}{l}\text { Data berhasil dimasukan kedalam } \\
\text { data customer }\end{array}$ \\
\hline Kesimpulan & (x) Diterima, () Ditolak \\
\hline \multicolumn{2}{|c|}{ Kasus dan Uji Hasil ( Data Belum lengkap ) } \\
\hline Data masukan & $\begin{array}{l}\text { Data customer yang diinputkan } \\
\text { belum lengkap }\end{array}$ \\
\hline $\begin{array}{l}\text { Yang } \\
\text { diharapkan }\end{array}$ & $\begin{array}{l}\text { Data customer yang diinputkan } \\
\text { belum lengkap dan menampilkan } \\
\text { pesan kesalahan berupa pesan dialog }\end{array}$ \\
\hline Pengataman & $\begin{array}{l}\text { Data yang dimasukan tidak berhasil } \\
\text { karena belum lengkap }\end{array}$ \\
\hline
\end{tabular}




\begin{tabular}{|c|c|}
\hline Kesimpulan & (x) Diterima, ( ) Ditolak \\
\hline \multicolumn{2}{|c|}{$\begin{array}{c}\text { TABEL VII } \\
\text { PENGUJIAN FORM BARANG } \\
\end{array}$} \\
\hline \multicolumn{2}{|c|}{ Kasus dan Hasil UJi ( Data Normal) } \\
\hline Data Masukan & Id barang,nama, satuan, harga \\
\hline Yang diharapkan & $\begin{array}{l}\text { Data barang berhasil disimpan ke } \\
\text { database }\end{array}$ \\
\hline Pengamatan & $\begin{array}{l}\text { Data berhasil dimasukan kedalam } \\
\text { data barang }\end{array}$ \\
\hline Kesimpulan & (x) Diterima, ( ) Ditolak \\
\hline \multicolumn{2}{|c|}{ Kasus dan Uji Hasil ( Data Belum lengkap ) } \\
\hline Data masukan & $\begin{array}{l}\text { Data barang yang diinputkan belum } \\
\text { lengkap }\end{array}$ \\
\hline Yang diharapkan & $\begin{array}{l}\text { Data barang yang diinputkan belum } \\
\text { lengkap dan menampilkan pesan } \\
\text { kesalahan berupa pesan dialog }\end{array}$ \\
\hline Pengataman & $\begin{array}{l}\text { Data yang dimasukan tidak berhasi } \\
\text { karena belum lengkap }\end{array}$ \\
\hline Kesimpulan & (x) Diterima, ( ) Ditolak \\
\hline
\end{tabular}

TABEL VIII

PENGUJIAN FORM TRANSAKSI

\section{Kasus dan Hasil UJi ( Data Normal)}

\begin{tabular}{|c|c|}
\hline Data Masukan & $\begin{array}{lr}\text { Id transaksi,tgl transaksi,jenis } \\
\text { transaksi, negara asal,negara } \\
\text { tujuan,unit } & \text { satuan,detail } \\
\text { paket,volume transaksi,total } \\
\text { pembayaran,terbilang,bulan } \\
\text { jatuh } \\
\text { transaksi,nama cst,nama user,tgl } \\
\text { jatuh tempo,tenggang waktu } \\
\text { pembayaran,sisa }\end{array}$ \\
\hline Yang diharapkan & $\begin{array}{l}\text { Data transaksi berhasil disimpan } \\
\text { ke database }\end{array}$ \\
\hline Pengamatan & Data berhasil ditampilkan \\
\hline Kesimpulan & (x) Diterima, ( ) Ditolak \\
\hline \multicolumn{2}{|c|}{ Kasus dan Uji Hasil ( Data salah ) } \\
\hline Data masukan & $\begin{array}{l}\text { Data transaksi yang diinputkan } \\
\text { belum lengkap }\end{array}$ \\
\hline Yang diharapkan & $\begin{array}{l}\text { Data transaksi yang diinputkan } \\
\text { belum lengkap dan } \\
\text { menampilkan pesan kesalahan } \\
\text { berupa pesan dialog }\end{array}$ \\
\hline Pengataman & $\begin{array}{l}\text { Data yang dimasukan tidak } \\
\text { berhasil }\end{array}$ \\
\hline Kesimpulan & (x) Diterima, ( ) Ditolak \\
\hline \multicolumn{2}{|c|}{$\begin{array}{c}\text { TABEL IX } \\
\text { PENGUJIAN FORM PENERIMAAN KAS }\end{array}$} \\
\hline \multicolumn{2}{|c|}{ Kasus dan Hasil UJi ( Data Normal) } \\
\hline Data Masukan & \begin{tabular}{l|lr} 
Id kas, tanggal kas, id \\
transaksi,
\end{tabular}$\quad \begin{array}{l}\text { jumlah } \\
\end{array}$ \\
\hline
\end{tabular}

\begin{tabular}{|c|c|}
\hline & penerimaan kas \\
\hline Yang diharapkan & $\begin{array}{l}\text { Data penerimaan berhasil } \\
\text { disimpan ke database }\end{array}$ \\
\hline Pengamatan & Data berhasil ditampilkan \\
\hline Kesimpulan & (x) Diterima, ( ) Ditolak \\
\hline \multicolumn{2}{|c|}{ Kasus dan Uji Hasil ( Data salah ) } \\
\hline Data masukan & $\begin{array}{l}\text { Data penerimaan yang } \\
\text { diinputkan belum lengkap }\end{array}$ \\
\hline Yang diharapkan & $\begin{array}{lr}\text { Data penerimaan } & \text { yang } \\
\text { diinputkan belum lengkap } \\
\text { dan menampilkan pesan } \\
\text { kesalahan berupa pesan } \\
\text { dialog }\end{array}$ \\
\hline Pengataman & $\begin{array}{l}\text { Data yang dimasukan tidak } \\
\text { berhasil }\end{array}$ \\
\hline Kesimpulan & (x) Diterima, () Ditolak \\
\hline
\end{tabular}

TABEL $X$

PENGUJIAN FORM CETAK LAPORAN TRANSAKSI

\begin{tabular}{|l|l|}
\hline \multicolumn{3}{|c|}{ Kasus dan Hasil UJi ( Data Normal) } \\
\hline Data Masukan & $\begin{array}{l}\text { Laporan transaksi yang ingin } \\
\text { dicetak, kategori yang } \\
\text { ditampilkan }\end{array}$ \\
\hline Yang diharapkan & $\begin{array}{l}\text { Muncul laporan Transaksi kategori } \\
\text { yang diinginkan }\end{array}$ \\
\hline Pengamatan & Data berhasil ditampilkan \\
\hline Kesimpulan & (x) Diterima, () Ditolak \\
\hline Kasus dan Uji Hasil ( Data salah ) \\
\hline Data masukan & $\begin{array}{l}\text { Laporan transaksi yang ingin } \\
\text { dicetak, kategori yang ingin } \\
\text { ditampilkan }\end{array}$ \\
\hline Yang diharapkan & $\begin{array}{l}\text { Tidak muncul laporan transaksi dan } \\
\text { kategori yang diinginkan }\end{array}$ \\
\hline Pengataman & Data tidak berhasil ditampilkan \\
\hline Kesimpulan & (x) Diterima, ( ) Ditolak \\
\hline
\end{tabular}

TABEL XI

PENGUJIAN FORM CETAK PENERIMAAN KAS

Kasus dan Hasil UJi ( Data Normal)

\begin{tabular}{|l|l|}
\hline Data Masukan & $\begin{array}{l}\text { Laporan penerimaan kas yang ingin } \\
\text { dicetak, kategori yang ingin } \\
\text { ditampilkan }\end{array}$ \\
\hline Yang diharapkan & $\begin{array}{l}\text { Muncul laporan penerimaan kas } \\
\text { kategori yang diinginkan }\end{array}$ \\
\hline Pengamatan & Data berhasil ditampilkan \\
Kesimpulan & (x) Diterima, () Ditolak \\
\hline Kasus dan Uji Hasil ( Data salah ) \\
\hline Data masukan & $\begin{array}{l}\text { Laporan penerimaan kas yang ingin } \\
\text { dicetak, kategori yang ingin } \\
\text { ditampilkan }\end{array}$ \\
\hline Yang diharapkan & $\begin{array}{l}\text { Tidak muncul laporan penerimaan } \\
\text { kas dan kategori yang diinginkan }\end{array}$ \\
\hline Pengataman & Data tidak berhasil ditampilkan \\
\hline Kesimpulan & (x) Diterima, () Ditolak \\
\hline
\end{tabular}




\section{A. Simpulan}

\section{KESIMPULAN}

Berdasarkan hasil penelitian, identifikasi masalah serta pembahasan sistem dianalisis yang dilakukan,maka dapat diambil kesimpulan sebagaiz berikut :

1. Sistem Informasi Akuntansi Penerimaan Kas yang berjalan pada CV Bintang Alpro masih mengunakan manual seperti mendata orderan costumer, melakukan pembukuan laporan melalui tulisan, sehingga tidak efektif dan proses pencarian data memakan waktu dan kendala human error sangat mudah terjadi.

2. Masalah yang dihadapi CV. Bintang Alpro dalam menghasilkan Informasi Peneriman Kas yaitu terkendala dalam menghasilkan Laporan karena memerlukan waktu yang lama dalam mencari data dan proses transaksi terkendala waktu dikarenakan tidak ada database yang tersimpan, proses pelaporan Penerimaan Kas sering mengalami perbedaan jumlah dengan transaksi yang terjadi. Hal ini dikarenakan setiap transaksi tidak disimpan dalam sebuah sistem yang berbasis data (database)

3. Perancangan Sistem Informasi Penerimaan Kas pada CV. Bintang Alpro menggunakan waterfall dengan media Microsoft Visual Studio 2010 serta Microsoft Office Access 2003 sebagai penunjang pembuatan sistem Komputerisasi Akuntansi Penerimaan Kas yang dibuat untuk mempermudah proses penglaporan Penerimaan Kas dimana hal ini dapat menunjang proses administrasi dan ketepatan data.

\section{B. Saran}

Penulis menyadari bahwa pada sistem akuntansi penerimaan kas ini masih memiliki banyak kekurangan. Untuk itu apabila sistem infromasi penerimaan kas ini akan dilanjutkan,maka penulis memberikan saran yaitu sebagai berikut :

1. Perangkat lunak yang telah disarankan penulis ini,agar dapat diterapkan dan disarankan pula untuk melakukan pengembangan perancangan sistem lebih lanjut agar menjadi sistem yang lebih baik lagi.

2. Untuk menjaga agar sistem berfungsi dengan baik,maka diperlukan maintenance/ perawatan secara berkala.

\section{DAFTAR PUSTAKA}

[1] Susanto, Azhar, Sistem Informasi Manajemen Konsep dan Pengembangannya. Bandung: Lingga Jaya, 2004.

[2] Jogiyanto, Analisis dan Desain Sistem Informasi. Yogyakarta: BPFE, 2005.

[3] S.R, Soemarso, Akuntasnsi Suatu Pengantar. Jakarta: Salemba Empat, 2004.
[4] Theodorus M, Tuanakotta, Teori Akuntansi. Jakarta: Fakultas Ekonomi Universitas Indonesia, 2000.

[5] Mulyadi, Sistem Akuntansi. Jakarta: Salemba Empat, 2001. 